\title{
The colonic groove of the plains viscacha (Lagostomus maximus): Histochemical evidence of an abrupt change in the glycosylation pattern of goblet cells
}

\author{
María Florencia Tano de la $\mathrm{Hoz}^{1,2}$ | Mirta Alicia Flamini ${ }^{3}$ | \\ Carolina Natalia Zanuzzi ${ }^{2,3,4}$ | Alcira Ofelia Díaz ${ }^{1}$
}

\begin{abstract}
${ }^{1}$ Departamento de Biología, Instituto de Investigaciones Marinas y Costeras (IIMyC), Universidad Nacional de Mar del Plata, CONICET, FCEyN, Funes $32503^{\circ}$ piso, Mar del Plata 7600, Argentina

${ }^{2}$ Consejo Nacional de Investigaciones Científicas y Técnicas (CONICET), Argentina

${ }^{3}$ Laboratorio de Histología y Embriología Descriptiva, Experimental y Comparada, Departamento de Ciencias Básicas, Facultad de Ciencias Veterinarias, Universidad Nacional de La Plata, La Plata 1900, Argentina

${ }^{4}$ Instituto de Patología, "Prof. Dr. Bernardo Epstein", Facultad de Ciencias Veterinarias, Universidad Nacional de La Plata, La Plata 1900, Argentina
\end{abstract}

\section{Correspondence}

Alcira Ofelia Díaz, Instituto de Investigaciones Marinas y Costeras (IIMyC), FCEyN, CONICET-Universidad Nacional de Mar del Plata. Funes $32503^{\circ}$ piso, 7600 Mar del Plata, Buenos Aires, Argentina. Email: adiaz@mdp.edu.ar

\section{Funding information}

This research was supported by a Grant from Universidad Nacional de Mar del Plata (EXA 765/16), Buenos Aires, Argentina.

\begin{abstract}
The ascending colon of most rodent species shows a longitudinal colonic groove that works as a retrograde transport pathway for a mixture of bacteria and mucus toward the cecum. We describe the morphology and glycosylation pattern of the colonic groove of Lagostomus maximus to analyze the role of mucins in this anatomical feature. We also studied the distribution pattern of the interstitial cells of Cajal (ICC) to evaluate their regulatory influence on gut motility. The groove originated near the cecocolic junction and extended along the mesenteric side of the ascending colon, limited at both ends by nonpapillated ridges. These ridges divided the lumen of the ascending colon into two compartments: a narrow channel and a large channel, called the groove lumen and the main lumen, respectively. The histochemical analysis showed differences in the glycosylation pattern of the goblet cells inside and outside the groove. Unlike the mucosa lining the main lumen of the colon, the groove was rich in goblet cells that secrete sulfomucins. The PA/Bh/ $\mathrm{KOH}$ / PAS technique evidenced an abrupt change in the histochemical profile of goblet cells, which presented a negative reaction in the groove and a strongly positive one in the rest of the colonic mucosa. The anti-c-kit immunohistochemical analysis showed different ICC subpopulations in the ascending colon of L. maximus. Of all types identified, the ICC-SM were the only cells located solely within the colonic groove.
\end{abstract}

\section{KEYWORDS}

colonic separation mechanism, glycoconjugates, hystricognathi, interstitial cells of Cajal, morphology

\section{1 | INTRODUCTION}

Cecotrophy is a physiological mechanism described in small herbivore species and it consists of the production and ingestion of a special type of feces derived from caecal contents (Björnhag \& Snipes, 1999; Sakaguchi, 2003). Diverse studies have demonstrated that ingested feces have a larger content of proteins, vitamins and bacteria as well as a lesser proportion of fibers than the nonswallowed feces (Takahashi \& Sakaguchi, 1998, 2000). The formation of two types of feces, one with high protein content (soft feces or cecotrophs) and another fiber-rich (hard feces), is possible in different species of herbivore mammals due to the existence of a colonic separation mechanism (CSM). Even though the identification of both types is evident in lagomorphs (rabbits and hares) the formation of cecotrophs has also been demonstrated in caviomorph rodents (Martino, Zenuto, \& Busch, 2007; Mess \& Ade, 2005; Takahashi \& Sakaguchi, 1998, 2000).

Unlike lagomorphs, which possess a "particle dependent" CSM, most rodents have "mucus dependent" CSM; that is, bacteria are trapped by mucus and transferred through the colonic groove by antiperistalic movements into the cecum (Kotzé, van der Merwe, Ndou, O'Riain, \& Bennett, 2009; Takahashi \& Sakaguchi, 2000). As a result of the CSM, the bacteria do not release with feces but they accumulate in 
the cecum, the site of bacterial fermentation. The material separated by CSM is excreted because of the cecum contraction, and then reingested.

In general, the main method to demonstrate cecotrophy is the direct observation of certain positions and movements characteristic of this behavior (the majority of rodents bend the head to bring the mouth to the anus), as well as the differential analysis of soft and hard feces. However, this behavior is difficult to observe in some wild rodents with fossorial and nocturnal habits such as in the case of the plains viscacha (Lagostomus maximus) (Clauss, Besselmann, Schwarm, Ortmann, \& Hatt, 2007). The plains viscacha (Desmarest, 1817) is a caviomorph rodent belonging to the Chinchilidae that lives in arid, semiarid and humid regions of Argentina, Bolivia, and Paraguay. It is a gregarious animal that presents fossorial habits and lives in communal cave systems known as vizcacheras (Jackson, Branch, \& Villarreal, 1996). At twilight they leave their caves in search of food, especially grasses and dicotyledons (Bontti, Boo, Lindström, \& Elia, 1999; Branch, Villarreal, Sbriller, \& Sosa, 1994; Puig, Videla, Cona, Monge, \& Roig, 1998). Recent studies using markers for digestibility assays have shown that L. maximus, like other hystricomorph rodents has a longitudinal colonic groove and re-ingests its own feces (Clauss et al., 2007; Hagen et al., 2015). Also, studies based on passage of ingest have shown the existence of "mucus dependent" CSM in L. maximus (Hagen et al., 2015). The available information on the digestive physiology of L. maximus makes it an interesting species for the study of this morphological adaptation to herbivory.

The mucus is a permeable gel layer, mainly composed of water and mucins; it covers the mucosa of the vertebrate gastrointestinal tract. Mucins are highly glycosylated proteins Bansil and Turner, 2006 synthesized chiefly by goblet cells of the intestinal epithelium. It was demonstrated that among their functions they enable nutrient interchange with the underlying epithelium, protect the mucosa against proteolytic injury and are the main attachment site of commensal and pathogenic bacteria (Hansson, 2012; Kim \& Ho, 2010).

In vertebrates, mucins exhibit different glycosylation patterns due to the diverse length, branching and acetylation of the oligosaccharide chains (Forstner, Oliver, \& Sylvester, 1995). According to the glycans' chemical characteristics, mucins can be classified into neutral and acidic. In turn, acidic mucins can be subdivided into sulfomucins or sulfated mucins, and sialomucins (glycoproteins with sialic acid residues) (Beyaz \& Liman, 2009). The physicochemical characteristics of mucins are determined mainly by their composition and their content of glycans (Liquori et al., 2012). Consequently, the analysis of the glycosylation pattern of mucins has been widely used in diverse studies to infer its physiological role (Mastrodonato, Mentino, Liquori, \& Ferri, 2013; Scillitani \& Mentino, 2015; Tano de la Hoz, Flamini, \& Díaz, 2014, 2016).

Although it has been suggested that mucus play a key role in bacteria transport through the longitudinal colonic groove, there is paucity in the literature of studies determining the histochemical characteristics of mucins in that region. Moreover, no exhaustive research on the rodents' histochemical profile of the colonic groove has been reported (Kotzé et al., 2009; Snipes, Hörnicke, Björnhag, \& Stahl, 1988). In this article, we aim to study the morphological and histochemical characteristics of the colonic groove of L. maximus to analyze the role of mucins in this anatomical feature. In addition, we described the pattern of distribution of the interstitial cells of Cajal (ICC), that is, cellular pacemakers in close contact with nerve cells in the muscular layer, to determine a possible implication between their distribution and the regulation of the motility of the colonic groove. These cells are a critical component in enteric neuromuscular transmission. Advances in the last decades have shown that ICC play an important role in coordinating intestinal motility (Mazzone \& Farrugia, 2007).

\section{2 | MATERIALS AND METHODS}

\section{$2.1 \mid$ Animals}

Adult viscachas, Lagostomus maximus (Desmarest, 1817) of both sexes ( $n=14$, 8 females and 6 males) weighing between 4 and $5.5 \mathrm{~kg}$ were obtained from the Estación de Cría de Animales Silvestres (ECAS; Wild Animals Breeding Station), Ministry of Agro Industry of the Province of Buenos Aires (Argentina). The captured animals were anesthetized with a dose of xylacine ( $8 \mathrm{mg} / \mathrm{kg}$ body weight) followed by ketamine (50 mg/kg body weight) by intramuscular injection (Ketanest, Laboratorio Scott Cassara). Once deep anesthesia was reached, intracardiac perfusion with physiological saline solution and then with $4 \%$ paraformaldehyde in $0.1 \mathrm{~mol} \mathrm{~L}^{-1}$ phosphate buffer was performed. The protocol was approved by the Institutional Committee for the Care and Use of Laboratory Animals at the National University of La Plata (52-415T) and was in compliance with the international recommendations for experimental animals (Commission on Life Sciences National Research Council, 1996; Zuñiga, Tur Marí, Milocco, \& Pineiro, 2001).

\section{2 | Sampling and morphological study}

The necropsy was performed immediately after euthanasia by isolating the ascending colon. The inner mucosa was exposed with a cut along the antimesenterial border. Once the colonic mucosa was exposed, photographs were taken of the colonic groove along its entire length. The shape of the grooves was recorded. Transverse sections of the cranial portion, the medial third, and the terminal portion of the ascending colon were taken for histological and histochemical analysis. Samples were routinely processed and embedded in paraffin wax. Histological sections of $4 \mu \mathrm{m}$ thickness were stained with hematoxylin-eosin (H-E). Microphotographs were taken with an Olympus microscope, $\mathrm{CH} 30$ (Olympus; www.olympus.com).

\section{3 | Histochemistry}

For the characterization of glycoconjugates (GCs) the histological sections were also subjected to the following histochemical techniques:

1. Periodic acid Schiff (PAS) to demonstrate GCs with oxidizable vicinal diols and glycogen (Mc Manus, 1948). 
2. $\alpha$-amylase-PAS. Before the PAS technique, sections were subjected to an enzymatic digestion with $\alpha$-amylase for glycogen identification (Pearse, 1985).

3. $\mathrm{KOH} / \mathrm{PA}^{*} \mathrm{~S}$ (saponification- selective periodic acid- Schiff's reactive) for characterization of GCs with sialic acid residues. The saponification reaction $(\mathrm{KOH})$ was performed with $0.5 \%$ sodium hydroxide in $70 \%$ ethanol for 30 ' at room temperature. Before the Schiff's reactive, sections were subjected to a selective oxidation with $0.4 \mathrm{mmol} \mathrm{L}^{-1}$ periodic acid in $1.0 \mathrm{mmol} \mathrm{\textrm {L } ^ { - 1 }}$ hydrochloric acid at $4^{\circ} \mathrm{C}$ (Culling, Reid, \& Dunn, 1976).

4. $\mathrm{PA} / \mathrm{Bh} / \mathrm{KOH} / \mathrm{PAS}$ (periodic acid - reduction with borohydride saponification- periodic acid-Schiff's reactive) for presence of GCs with sialic acid residues with $\mathrm{O}$-acyl substitutions in ${ }^{7} \mathrm{C},{ }^{8} \mathrm{C}$ o ${ }^{9} \mathrm{C}$, and O-acyl sugars. This method was carried out using a 2 $\mathrm{hr}$ oxidation at room temperature with $1 \%$ periodic acid. The aldehydes generated by the initial oxidation were reduced to primary alcohols with sodium borohydride. After saponification $(\mathrm{KOH})$ the PAS technique (Reid, Culling, \& Dunn, 1973) was applied.

5. $\mathrm{KOH} / \mathrm{PA}^{*} / \mathrm{Bh} / \mathrm{PAS}$ (saponification- selective periodic acid- reduction with borohydride- periodic acid- Schiff's reactive) to identify neutral sugars. Sections were treated with $0.5 \%$ potassium hydroxide in $70 \%$ ethanol for $15 \mathrm{~min}$ at ambient temperature. Previous to the PAS technique a selective periodic oxidation at $4^{\circ} \mathrm{C}$ for $1 \mathrm{hr}$ followed by a reduction with sodium borohydride was performed (Volz, Reid, Park, Owen, \& Dunn, 1987).

6. AB (Alcian Blue) is a basic dye that has affinity for tissue components that possess anionic groups such as acidic GCs. AB solutions at different $\mathrm{pH}$ were used to selectively stain subgroups of acidic mucins. A staining solution ( $\mathrm{pH}$ 2.8) was used to evidence GCs with carboxylic groups and O-sulfated esters; sulfated GCs were identified with a pH 1.0 solution and GCs highly sulfated with a $\mathrm{pH} 0.5$ (Lev \& Spicer, 1964).

7. AB/PAS (Alcian Blue - periodic acid Schiff). This combined technique allows the identification of acid (AB positive), neutral (PASpositive), and mixed (AB/PAS positive) GCs in one section Mowry, 1963. The $A B$ solution was used at pHs 2.8 and 1.0 to identify carboxylated and sulfated GCs, and GCs with O-sulfated esters, respectively (Mowry, 1963).

8. TB (toluidine blue). This basic dye has affinity for acidic components of tissues, such as chromatin. Glycoconjugates with carboxylic groups and O-sulfated esters were evidenced with an TB solution at $\mathrm{pH} 5.6$ and sulfated GCs at pH 4.2 (orthochromatia) Moreover, this dye can stain polyanionic polymers of high molecular weight with a color different from the original tint (metachromatia) (Lison, 1953).

The results were evaluated by four independent observers using a semi-quantitative scale to determinate the intensity of the reactions (0, negative; 1 , light; 2 , moderate; 3 , strong). These scores were established according to previous histochemical studies (Scillitani \& Mentino, 2015; Tano de la Hoz et al., 2014, 2016).

\section{4 | Lectin-histochemistry}

A battery of seven biotinylated lectins (Vector Laboratories, Inc. Burlingame, CA) was used to identify specific sugar residues (Table 1). The paraffin sections were mounted on slides treated with polyL-lysine (Sigma Diagnostics, St Louis, MO), deparaffinated with xylol and incubated in a $0.3 \% \mathrm{H}_{2} \mathrm{O}_{2}$ solution in methanol for $30 \mathrm{~min}$ at room temperature to inhibit the endogenous peroxidase activity. Then, the sections were hydrated, washed with $0.01 \mathrm{~mol} \mathrm{~L}^{-1}, \mathrm{pH}$ 7.6 saline phosphate buffer (SPB) and incubated with a bovine serum albumin in SPB for 20 min to block specific bindings. After rinsing, sections were incubated with each of the biotinylated lectins for $30 \mathrm{~min}$ at room temperature and treated with avidine-biotineperoxidase complex (ABC) during $45 \mathrm{~min}$ (Vector Laboratories, Inc). The peroxidase was activated through 4-10 min incubation with a Tris- $\mathrm{HCl} 0.05 \mathrm{~mol} \mathrm{~L}^{-1}, \mathrm{pH} 7.6$ tamponed solution containing $0.02 \%$ diaminobenzine (DAB; Dako, Carpinteria, CA, EE.UU.), and $0.05 \% \mathrm{H}_{2} \mathrm{O}_{2}$. All lectins were employed in a $30 \mathrm{mg} \mathrm{m}^{-1}$ in SPB, except for PNA that was applied at concentration $10 \mathrm{mg} \mathrm{ml}^{-1}$.

The results were semi-quantitatively evaluated, using the same scale as the one used for the histochemical study. Two types of controls were made: (1) the lectin solution was replaced by SPB and (2) lectins were preincubated at ambient temperature for $1 \mathrm{hr}$ in presence of adequate haptens.

\section{5 | Immunohistochemical detection of interstitial cells of Cajal}

For the immunohistochemical analysis of immunohistochemical detection of interstitial cells of Cajal we used the Envision (Dako Corp.,Carpinteria, CA) method. A rabbit polyclonal antibody anti-c-kit (CD117; Dako, Japan A4502) was used as a primary antibody to detect ICC. The paraffin sections were mounted on Starfrost glass slides (Knittel, Braunschweig, Germany), deparaffinated with xylol and incubated in $0.3 \% \mathrm{H}_{2} \mathrm{O}_{2}$ in methanol for $30 \mathrm{~min}$ at room temperature. Then they were hydrated, washed with $0.01 \mathrm{~mol} \mathrm{~L}^{-1}, \mathrm{pH} 7.6 \mathrm{SPB}$, and microwave antigen retrieval was applied at $800 \mathrm{w}$ twice for 5 min each using $0.01 \mathrm{~mol} \mathrm{~L}^{-1}, \mathrm{pH} 6.0$ buffer citrate. After rinsing, sections were incubated with $1 \%$ bovine seric albumin for 30 min to block unspecific bindings. The sections were incubated with the primary antibody (1:50 dilution) for $1 \mathrm{hr}$ at $25^{\circ} \mathrm{C}$; negative controls were incubated with SPB under the same conditions. After incubation with the polymer, 3',3'-diaminobenzidine (DAB) and $0.05 \% \mathrm{H}_{2} \mathrm{O}_{2}$ were used. Finally, sections were counterstained with hematoxylin (BIOPUR), dehydrated and mounted.

\section{3 | RESULTS}

\section{1 | Morphological study}

The ascending colon of Lagostomus maximus exhibited a longitudinal colonic groove along the mesenteric side. The groove originated near the cecocolic junction and it was formed by two nonpapillated ridges (Figure 1a,b). These ridges divided the lumen of the ascending colon 
TABLE 1 Lectins used and their carbohydrate specificities

\begin{tabular}{|c|c|c|c|}
\hline Lectin & Acronym & Specificity & Haptene \\
\hline GROUP I & & Glc/Man & \\
\hline Canavalia ensiformisagglutinin & Con-A & $\alpha$-D-Man; $\alpha$-D-GlC & $\alpha$-D-Methyl-Man \\
\hline GROUP II & & GlcNAc & \\
\hline $\begin{array}{l}\text { Triticum vulgaris } \\
\text { (wheatgerm) agglutinin }\end{array}$ & WGA & $\beta$-D-GlcNAc; NeuNAc & NeuNAc \\
\hline GROUP III & & GalNAc/Gal & \\
\hline Dolichos biflorusagglutinin & DBA & $\alpha-D-G a l N A c$ & D-GalNAC \\
\hline Glycine maximusagglutinin & SBA & $\alpha$-D-GalNAc; $\beta$-D-GalNAc & D-GalNAC \\
\hline $\begin{array}{l}\text { Ricinus communis } \\
\text { Agglutinin-I }\end{array}$ & RCA-I & $\beta-G a l$ & Lactose \\
\hline Arachis hypogaeaagglutinin & PNA & $\beta-D-G a l(\beta 1-3)>D-G a l N A c$ & Lactose \\
\hline GROUP IV & & L-Fuc & \\
\hline $\begin{array}{l}\text { Ulex europaeus } \\
\text { Agglutinin-I }\end{array}$ & UEA-I & $\alpha-$-Fuc & L-Fuc \\
\hline
\end{tabular}

Gal, galactose; GalNAc, N-acetylgalactosamine; Glc, glucose; GlcNAc, N-acetylglucosamine; L-Fuc, L-fucose; Man, mannose; $\alpha$-D-Methyl-Man, $\alpha$-D-Methyl-mannose; NeuNAc, acetyl-neuraminic acid (sialic acid).
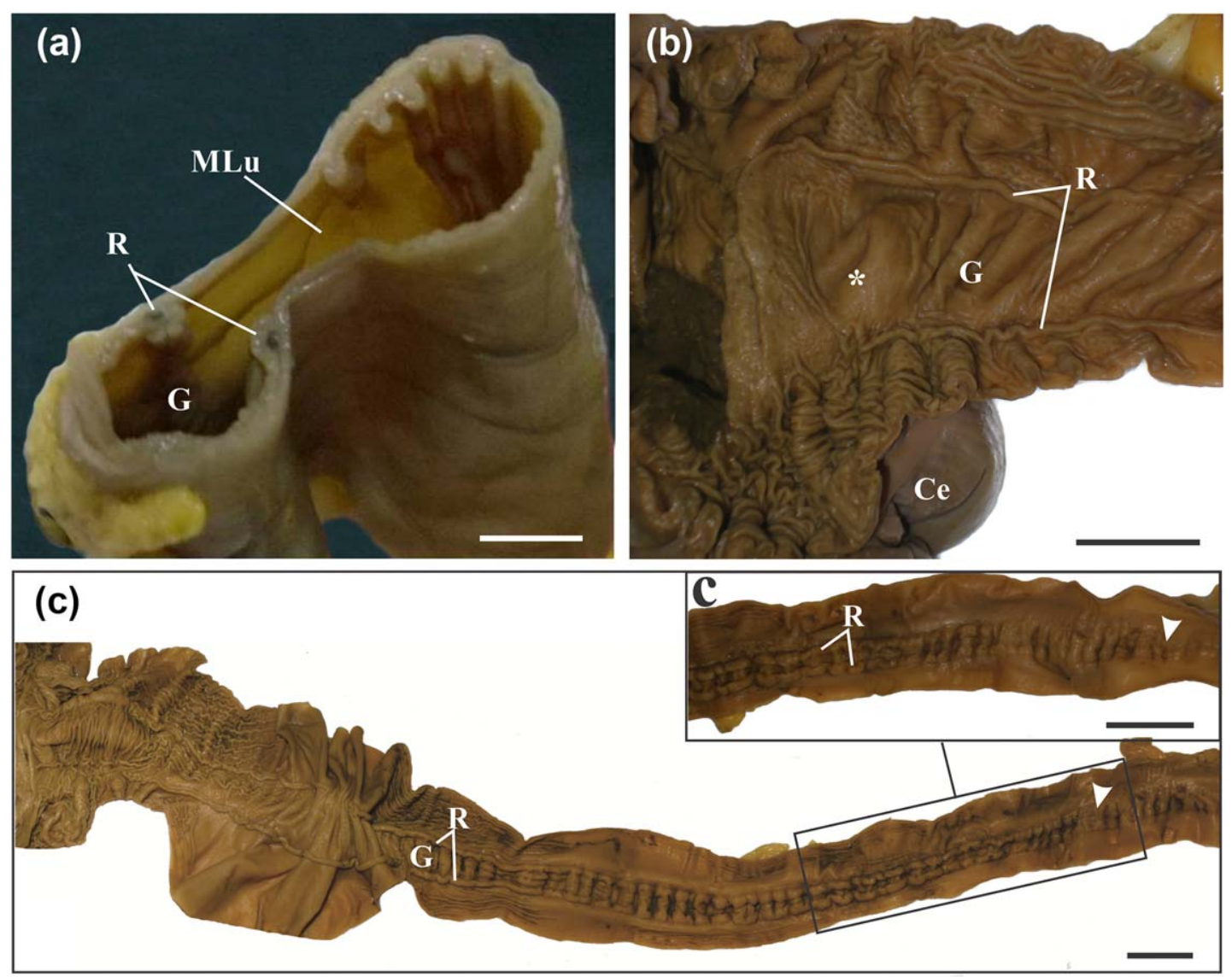

FIGURE 1 Lagostomus maximus, histological characterization of the longitudinal colonic groove. (a) Cross section of the ascending colon. (b) Macroscopic anatomy of the groove's origin. (c) Macroscopic view of the inner surface of the ascending colon. (d) Macroscopic view of the caudal region of the ascending colon. Arrow head, caudal region of the ascending colon where the groove disappeared; asterisk, cecocolic junction; Ce, cecum; G, groove; MLu, main lumen; R, ridge. Scale bar: $1 \mathrm{~cm}$ (a); $1.5 \mathrm{~cm}$ (b, c, d) 

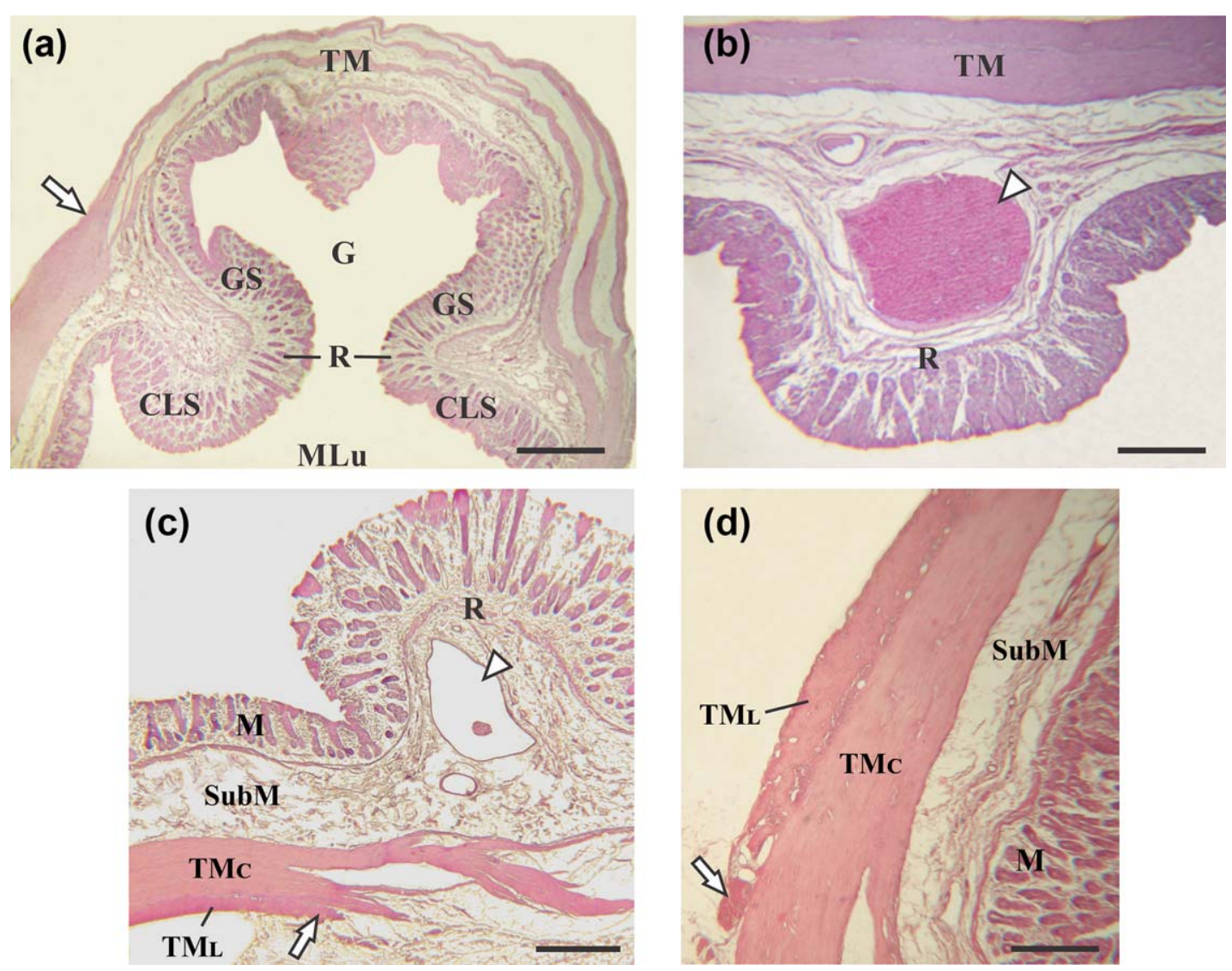

FIGURE 2 Lagostomus maximus, histological characterization of the longitudinal colonic groove, H-E. (a) Microphotography of the groove. (b) Nonpapillated ridge. (c) Detail of the abrupt change of the tunica muscularis morphology. (d) Detail of the tunica muscularis. Arrow head, large caliber vein; block arrow, morphological change of the tunica muscularis; CLS, lateral border of the ridge limiting with the main lumen; G, groove; GS, lateral border of the ridge limiting the groove; M, tunica mucosa; MLu, main lumen; R, ridge; SubM, tunica submucosa; TM, tunica muscularis; $T M_{C}$, inner circular layer of the tunica muscularis; $\mathrm{TM}_{\mathrm{L}}$, outer longitudinal layer of the tunica muscularis. Scale bar: 800 $\mu \mathrm{m}(\mathrm{a}) ; 400 \mu \mathrm{m}$ (b); $250 \mu \mathrm{m}$ (c); $100 \mu \mathrm{m}$ (d)

into two compartments: a narrow channel and a large channel, called the groove lumen and the main lumen, respectively (Figure 1a). The space separating the ridges gradually diminished along the colon producing a narrowing of the groove toward the distal region of the ascending colon, where it finally disappeared (Figure 1c,d). Every ridge showed two lateral edges: one that lines the main lumen and another that limits with the colonic groove named colonic luminal side (CLS) and groove side (GS), respectively (Figures 2a and 3). The center of the ridge consisted of an extension of the tunica submucosa characterized by large caliber veins (Figure 2b). The morphology of the tunica muscularis of the ascending colon abruptly changed at the height of the ridges. Instead of being formed by an inner circular layer and an outer longitudinal layer, as in most regions of the digestive tract, the tunica muscularis of the groove exhibited numerous bundles of circularly arranged smooth muscular fibers separated by abundant connective tissue (Figure 2a,c). Instead, the longitudinal outer layer gradually diminished its width until it finally disappeared within the groove (Figure $2 \mathrm{~d}$ ). Although the tunica muscularis of the groove presented only an inner circular layer, it was characterized by being thicker than the outer muscular layer of the ascending colon.

\section{2 | Histochemical study}

The analysis of glycoconjugates (GCs) revealed evident differences between the glycosylation patterns of goblet cells in and out of the colonic groove all along the ascending colon (Table 2). The change in histochemical profile of this cell type occurred with most techniques at the height of the colonic ridges. In all the specimens studied the mucosa lining the colonic luminal side of the ridge (CLS) showed a glycosylation pattern different to the one lateral to the ridge limiting the groove (GS; Figure 4).

The $\mathrm{AB} \mathrm{pH}$ 2.8/PAS method allowed the identification of goblet cells containing neutral, acidic and mixed mucins, both in the groove and the main lumen of the organ (Figure $4 a-d$ ). However, the distribution pattern of these unicellular glands differed noticeably between both sectors (Figure 4c,d). Goblet cells out of the groove showed a decreasing gradient of neutral GCs from the upper to the lower region of the crypts, and PAS and AB/PAS positive cells were found in the upper third of the gland. Goblet cells from the basal zone showed a histochemical pattern different to the rest of the cells, exhibiting mainly carboxylated GCs (Figure 4c). In the groove, instead, all three cell types were identified, although distributed along all the axis of the intestinal gland (Figure 4d). 


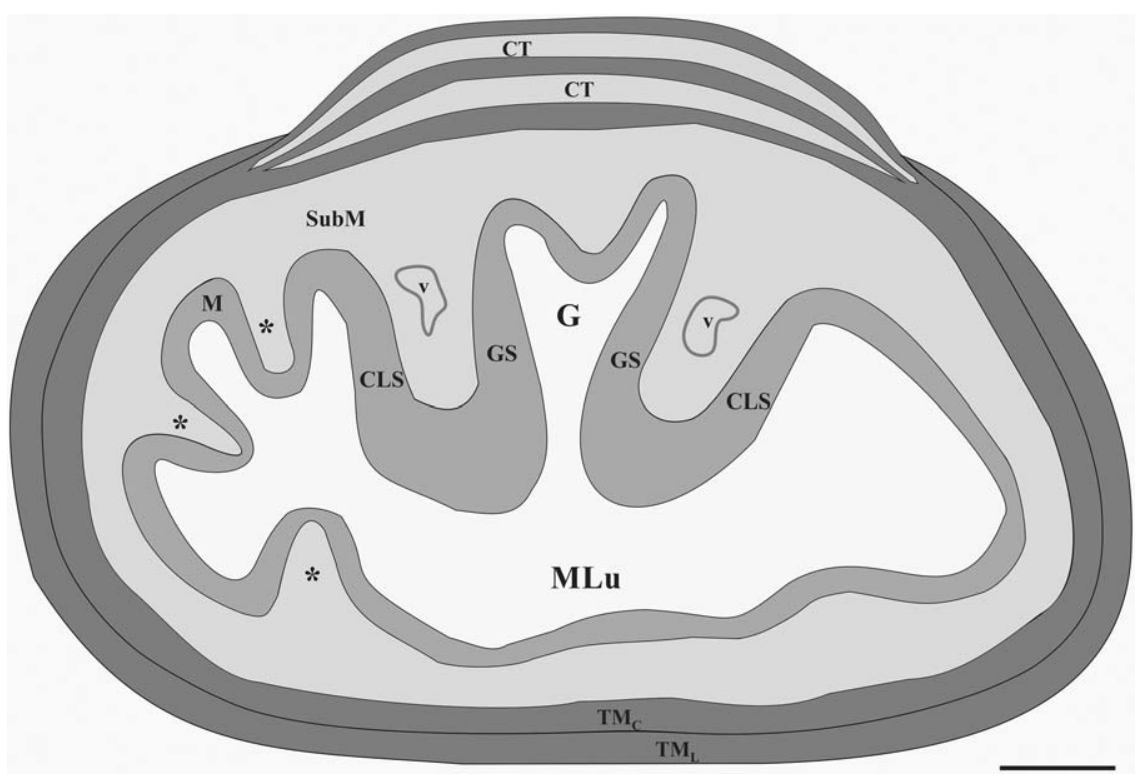

FIGURE 3 Scheme of general histological characteristics of the colonic groove. Asterisk, folds; CSL, lateral border of the ridge limiting the main lumen; CT, connective tissue; M, tunica mucosa; MLu, main lumen; G, groove; GS, lateral border of the ridge limiting the groove; SubM, tunica submucosa; $\mathrm{TM}_{\mathrm{C}}$, inner circular layer of the tunica muscularis; $\mathrm{TM}_{\mathrm{L}}$, outer longitudinal layer of the tunica muscularis; $\mathrm{v}$, large caliber vein. Scale bar: $2000 \mu \mathrm{m}$

Unlike the mucosa which lines the main lumen of the colon, the groove was characterized by secreting a high proportion of sulfomucins and GCs with polyanionic complexes (Figures 4e,f and 5a). Even though goblet cells from the main lumen also showed metachromatia with TB, at $\mathrm{pHs}$ both 5.6 and 4.2, this reaction was only observed in cells from the upper and medium region of the intestinal crypts (Figure $5 b$ ).
Goblet cells from both regions showed a moderate staining with the $\mathrm{KOH} / \mathrm{PA}^{*} \mathrm{~S}$ technique evidencing GCs with sialic acid residues (Figure $5 \mathrm{c}-\mathrm{e})$. However, the PA/Bh/KOH/PAS method showed an abrupt change in the histochemical profile of the cells, which presented a negative reaction in the groove and a strongly positive reaction in the rest of the colonic mucosa. These results demonstrated that only goblet

TABLE 2 Histochemical analysis of the ascending colon of Lagostomus maximus

\begin{tabular}{|c|c|c|c|c|c|c|c|c|}
\hline \multirow[b]{4}{*}{ Techniques } & \multicolumn{8}{|c|}{ Ascending colon } \\
\hline & \multicolumn{4}{|l|}{ Groove } & \multicolumn{4}{|l|}{ Main lumen } \\
\hline & \multirow[b]{2}{*}{ Glycocalyx } & \multicolumn{3}{|l|}{ Goblet cells } & \multirow[b]{2}{*}{ Glycocalyx } & \multicolumn{3}{|l|}{ Goblet cells } \\
\hline & & Uppercrypt & Medialcrypt & Lowercrypt & & Upper crypt & Medialcrypt & Lowercrypt \\
\hline PAS & 0 & 3 & 3 & 3 & 0 & 3 & 3 & 1 \\
\hline $\mathrm{AB}$ pH 2,8 & 0 & 3 & 3 & 3 & 0 & 3 & 3 & 3 \\
\hline $\mathrm{AB} \mathrm{pH} 1,0$ & 2 & 3 & 3 & 3 & 1 & 1 & 1 & 1 \\
\hline $\mathrm{AB} \mathrm{pH} 0,5$ & 2 & 3 & 3 & 3 & 1 & 1 & 1 & 1 \\
\hline $\mathrm{AB} \mathrm{pH} 2,8 / \mathrm{PAS}$ & 0 & $3 M-3 P-3 B^{a}$ & $3 M-3 P-3 B^{a}$ & $3 M-3 P-3 B^{a}$ & 0 & $3 M-3 P^{a}$ & $3 P$ & $3 B$ \\
\hline $\mathrm{AB} \mathrm{pH} 1,0 / \mathrm{PAS}$ & 1 & $3 M-3 P-3 B^{a}$ & $3 M-3 P-3 B^{a}$ & $3 M-3 P-3 B^{a}$ & 1 & $2 \mathrm{P}-2 \mathrm{M}^{\mathrm{a}}$ & $2 \mathrm{P}$ & $1 \mathrm{P}$ \\
\hline TB pH 5,6 & 0 & $3 m$ & $3 m$ & $3 m$ & 0 & $3 m$ & $3 m$ & 1or \\
\hline TB pH 4,2 & 0 & $3 m$ & $3 m$ & $3 m$ & 0 & $3 m$ & $3 m$ & 1or \\
\hline $\mathrm{KOH} / \mathrm{PA}^{\mathrm{a}} \mathrm{S}$ & 0 & 2 & 2 & 2 & 0 & 2 & 2 & 2 \\
\hline $\mathrm{PA} / \mathrm{Bh} / \mathrm{KOH} / \mathrm{PAS}$ & 0 & 0 & 0 & 0 & 0 & 2 & 2 & 2 \\
\hline $\mathrm{KOH} / \mathrm{PA}^{\mathrm{a}} / \mathrm{Bh} / \mathrm{PAS}$ & 0 & 3 & 3 & 3 & 0 & 3 & 3 & 3 \\
\hline
\end{tabular}

$\mathrm{m}$, metachromasia; M, magenta; or, ortochromasia; P, purple.

Staining intensity: 0 , negative; 1 , slightly positive; 2 , moderate; 3 , strong.

${ }^{a}$ Goblet cells with different histochemical profiles were differentiated. 

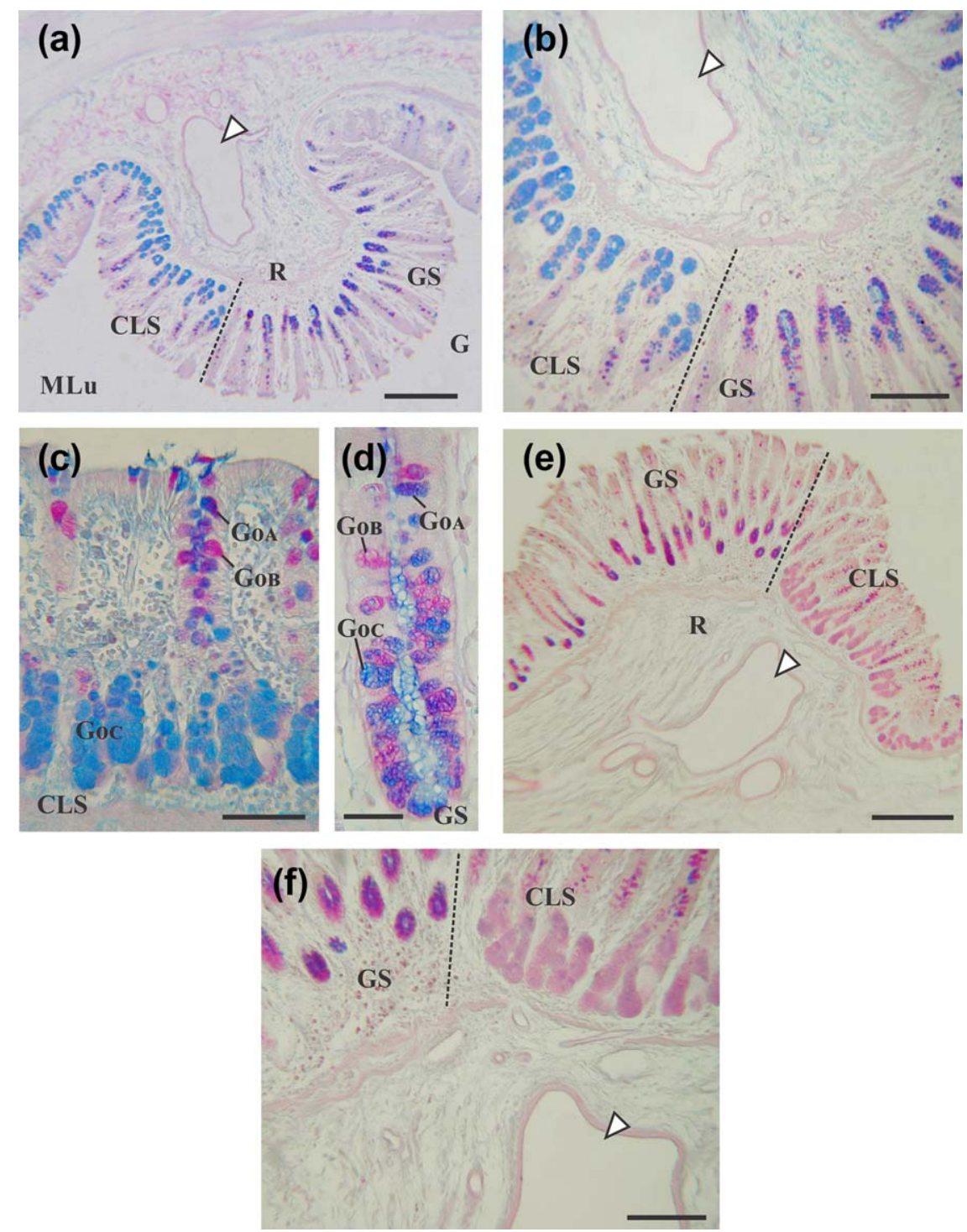

FIGURE 4 Lagostomus maximus, in situ characterization of the glycosylation pattern of the ascending colon. (a) Microphotography of a colonic ridge, $\mathrm{AB}$ pH 2.8/PAS. (b) Detail of figure (a) showing the abrupt change in the histochemical profile of goblet cells (see dotted line), $A B \mathrm{pH} 2.8$ / PAS. (c) Microphotography of the lateral ridge limiting the main lumen of the colon (CLS), AB pH 2.8/PAS. (d) Microphotography of a intestinal crypt in the side of the ridge limiting the colonic groove (GS), AB pH 2.8/PAS. (e) Nonpapillated ridge showing an abrupt change in the histochemical pattern of goblet cells (see dotted line), $A B \mathrm{pH}$ 1.0/PAS. (f) Detail of figure e, AB pH 1.0/PAS. Arrow head, large caliber vein; CLS, lateral border of the ridge limiting the main lumen; $G$, groove; $\mathrm{Go}_{\mathrm{A}}$, goblet cell $\mathrm{AB} / \mathrm{PAS}$ positive; $\mathrm{Go}_{\mathrm{B}}$, goblet cell $\mathrm{PAS}$ positive; $\mathrm{Go}$, goblet cell $\mathrm{AB}$ positive; GS, lateral border of the ridge limiting the groove; MLu, main lumen; R, ridge. Scale bar: $500 \mu \mathrm{m}(\mathrm{a}, \mathrm{e}) ; 250 \mu \mathrm{m}(\mathrm{b}, \mathrm{f}) ; 75 \mu \mathrm{m}(\mathrm{c}) ; 50 \mu \mathrm{m}(\mathrm{d})$

cells from the main lumen secrete GCs with sialic acid O-acyl substituted at C7, C8, or C9 (Figure 5f,g).

\section{3 | Lectin histochemical study}

The lectin histochemical method revealed different specific sugar residues in the groove and the main lumen of the ascending colon (Table 3). The Con-A, WGA, RCA-I, and PNA lectins showed the same binding pattern in both sectors, exhibiting an intense labeling both in the glycocalyx and the goblet cells (Figures 6a-d and 7c-f). However, the colonic groove showed a lectin histochemical profile that differs from the rest of the ascending colon in all the studied regions. The DBA lectin gave a negative reaction in the groove but a positive in the main lumen intensively labeling the glycocalyx and the goblet cells of the upper and medium regions of the intestinal glands (Figure 6e,f). Although the SBA lectin strongly labeled the glycocalyx of both sectors, it only showed affinity for goblet cells outside the groove (Figure 7a,b). Conversely, UEA-I evidenced L-fucose residues in goblet cells of the whole organ, except in cells in the base of the intestinal glands of the main lumen (Figure 7g,h).

\section{$3.4 \mid$ Immune histochemical study to detect interstitial cells of Cajal}

The ascending colon wall lining the main lumen presented cells strongly immunolabeled in the myenteric plexus and throughout the thickness 

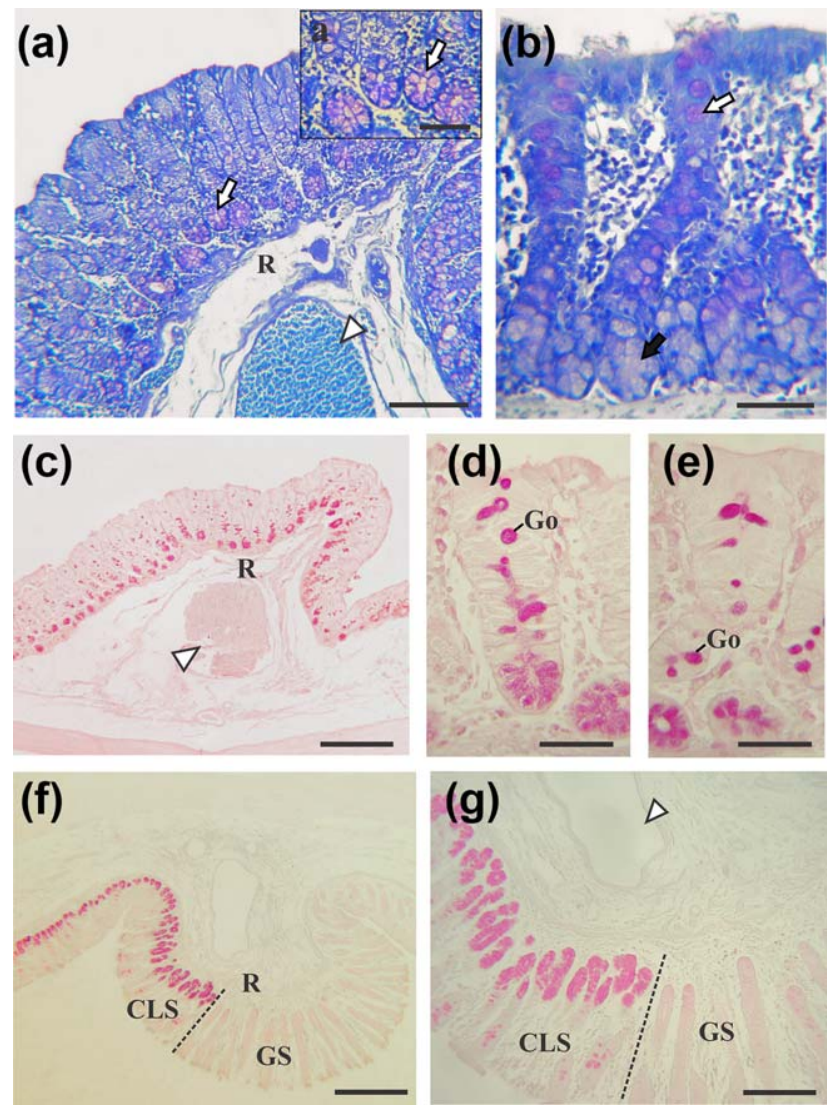

FIGURE 5 Lagostomus maximus, in situ characterization of the glycosylation pattern of the ascending colon. (a) Mucosa and submucosa of a colonic ridge, $\mathrm{TB} \mathrm{pH}$ 5.6. (a) Detail of the goblet cells at the basal region of the intestinal glands, TB pH 5.6. (b) Mucosa lining the main lumen of the colon, TB pH 5.6. (c) Ridge of the colonic groove, $\mathrm{KOH} / \mathrm{PA}^{*} \mathrm{~S}$. (d) Mucosa lining the main lumen, $\mathrm{KOH} / \mathrm{PA}^{*} \mathrm{~S}$. (e) Mucosa lining the colonic groove, KOH/PA*S. (f) Microphotography of a colonic ridge showing an abrupt change in the histochemical pattern of goblet cells (see dotted lines), PA/Bh/ $\mathrm{KOH} / \mathrm{PAS}$. (g) Detail of figure f. arrow head, large caliber vein; black arrow, goblet cells with orthochromatic reaction; CSL, lateral border of the ridge limiting the main lumen; Go, goblet cells; GS, lateral border of the ridge limiting with the groove; $\mathrm{R}$, ridge; white arrow, goblet cells with metachromatic reaction. Scale bar: $100 \mu \mathrm{m}$ (a); $50 \mu \mathrm{m}$ (b); $40 \mu \mathrm{m}$ (d, e); $250 \mu \mathrm{m}$ (c, f, g)

of the inner circular layer and the outer longitudinal layer of the tunica muscularis (Figure 8). Because of their location and morphology these cells are classified as myenteric ICC (ICC-MY) and intramuscular ICC (ICC-IM), respectively. The ICC-MY showed a multipolar morphology (Figure 8b) whereas the ICC-IM presented a fusiform body with few branched processes orientated according to the direction of the major axis of the muscle fiber (Figure 8a,c).

In the colonic groove ICC-IM were identified only in the inner circular layer (this region of the ascending colon lacks a longitudinal layer). Moreover, numerous c-kit positive cells were detected in the submucosal surface of the circular muscle (ICC-SM; Figure 9). This ICCsubpopulation extended from ridge to ridge, forming a continuous band of multipolar cells with thin, long, and interdigitated processes (Figure 10).
TABLE 3 Lectin histochemical analysis of the ascending colon of Lagostomus maximus

\begin{tabular}{|c|c|c|c|c|}
\hline \multirow{3}{*}{ Lectin } & \multicolumn{4}{|c|}{ Ascending colon } \\
\hline & \multicolumn{2}{|c|}{ Groove } & \multicolumn{2}{|l|}{ Main lumen } \\
\hline & Glycocalyx & Goblet cells & Glycocalyx & Goblet cells \\
\hline Con-A & 2 & 2 & 2 & 2 \\
\hline WGA & 3 & 2 & 3 & 2 \\
\hline DBA & 0 & 0 & 3 & $3^{a}$ \\
\hline SBA & 3 & 0 & 3 & 3 \\
\hline RCA-I & 3 & 2 & 3 & 2 \\
\hline PNA & 3 & 2 & 3 & 2 \\
\hline UEA-I & 1 & 2 & 1 & $2^{\mathrm{a}}$ \\
\hline
\end{tabular}

Staining intensity: 0 , negative; 1 , slightly positive; 2 , moderate; 3 , strong. ${ }^{a}$ Only the cells of the upper and middle region of the intestinal crypts presented positive reaction.

\section{4 | DISCUSSION}

\subsection{Comparison of the colonic groove morphology within hystricomorph rodents}

The colonic separation mechanism (CSM) has been studied in different species of lagomorphs and rodents (Björnhag \& Snipes, 1999; Hagen et al., 2015; Takahashi \& Sakaguchi, 2000). However, the histological characteristics of this adaptation to herbivory have been described only in few studies (Kotzé et al., 2009; Snipes et al., 1988). Our results show that although the anatomical and histological organization of the colonic groove of Lagostomus maximus is similar to that of other hystricomorph rodents, this species also possesses its own distinctive features. The colonic ridges of L. maximus has a center of connective tissue with irregular large caliber veins (Kotzé et al., 2009; Snipes et al., 1988). It is possible, as proposed by Kotzé et al. (2009) as seen in all rodent species that have been studied. These large veins supposedly generate the swelling of the ridges as a consequence of the high blood irrigation, and thus compartmentalize the lumen. Because the existence of these large veins has been described in every studied species, the groove closure mechanism may be common to all rodents. In some species of the African mole rats (Rodentia, Bathyergidae) the presence of projections at the end of the ridges that would further facilitate the closure of the groove (Kotzé et al., 2009). In contrast, no additional structures have been found in the ridges of L. maximus and Myocastor coypus to contribute to the separation of the main lumen of the groove.

Differences among species have also been observed in the structural organization of the tunica muscularis. Contrary to the description made by Kotzé et al. (2009) on the six species of Bathyergidae, in our study the tunica muscularis of L. maximus showed significant variations in both muscle layers in the colonic groove. It showed an inner circular layer formed by bundles of smooth muscle fibers separated by abundant connective tissue whereas the longitudinal outer layer gradually decreased in thickness and disappeared at the height of the ridges. 

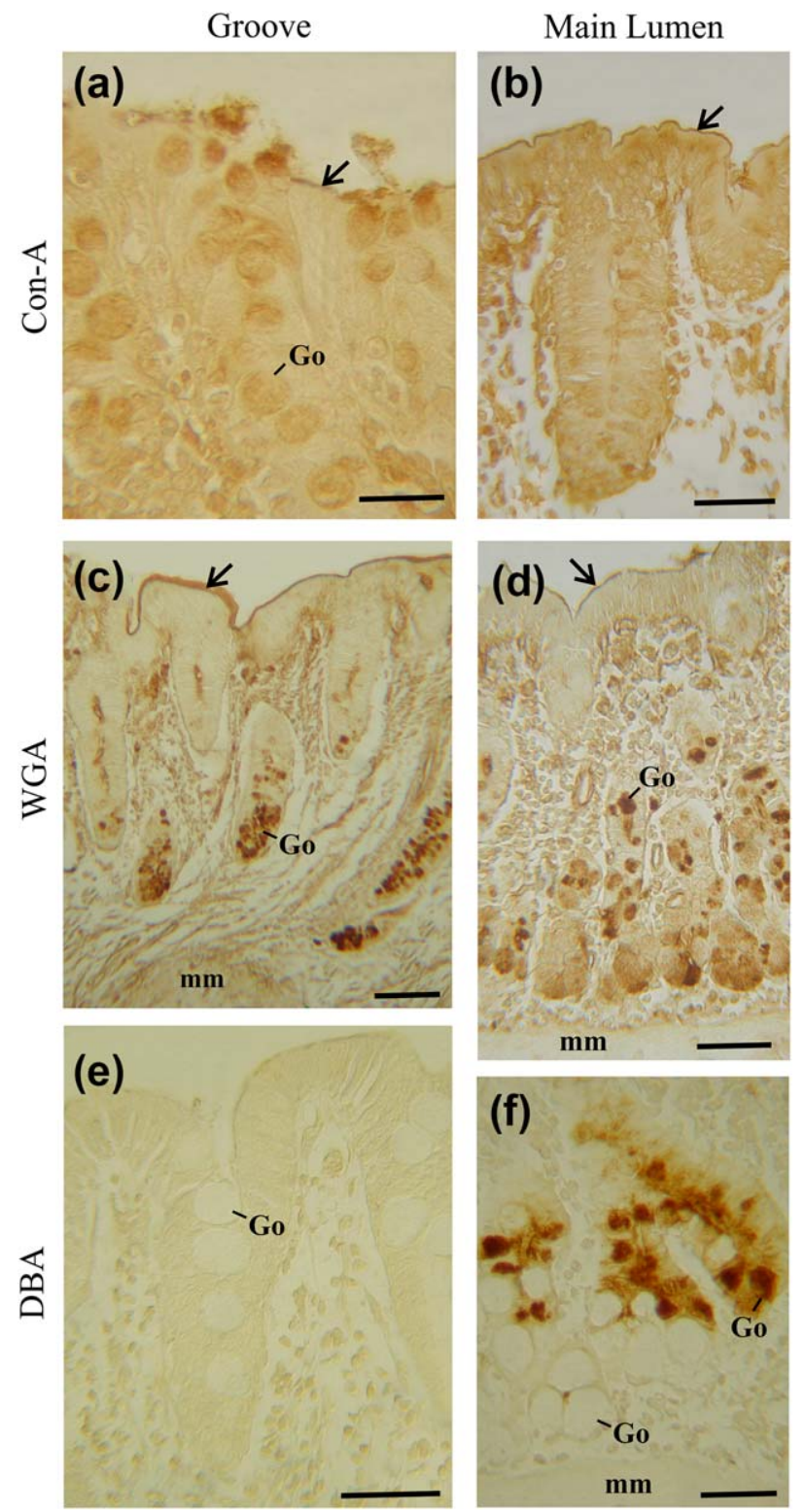

FIGURE 6 Lagostomus maximus, lectin histochemistry of the longitudinal colonic groove (a, c, e) and of the ascending colon wall lining the main lumen (b, d, f). (a, b) Con- A. (c, d) WGA. (e, f) DBA. Arrow, glycocalyx; Go, goblet cell; mm, muscular mucosa. Scale bar: $20 \mu \mathrm{m}$ (a); $30 \mu \mathrm{m}$ (b); $60 \mu \mathrm{m}$ (c); $40 \mu \mathrm{m}$ (d-f)

Similar histological characteristics were described for $M$. coypus although the organization of the bundles of the inner circular layer differed from that of L. maximus (Snipes et al., 1988). In contrast, an increase in thickness of the outer longitudinal layer exactly beneath the ridges that limit the groove was observed in six species of naked molerats (Kotzé et al., 2009). Although noticeable differences among species were observed, rodents show changes in the histological characteristics of the tunica muscularis at the height of the ridges. The high structural specialization of the muscle tissue is probably linked to the antiperistaltic movements in the colonic groove that transport the luminal content in a retrograde way (Takahashi \& Sakaguchi, 2006). It is likely that each muscle bundles of the inner circular layer of the tunica muscularis of
L. maximus may act as an individual functional unit that works together to carry out specific functions.

\subsection{Glycosylation pattern of L. maximus colonic groove: Functional implications}

Several studies have demonstrated that rodents transport through the CSM a mixture of bacteria and mucus from the ascending colon to the cecum to maintain the bacterial fermentation process (Snipes et al.,
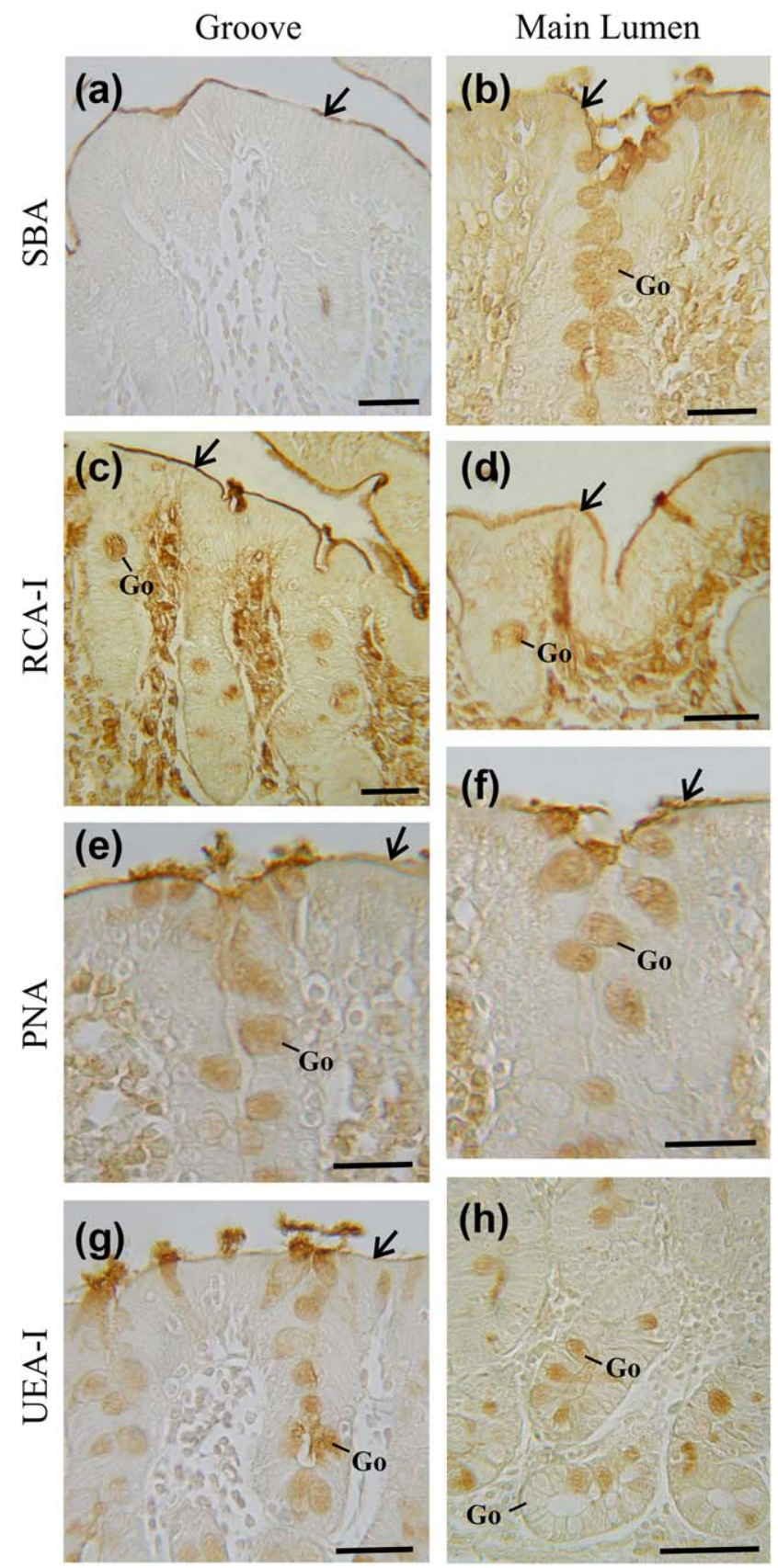

FIGURE 7 Lagostomus maximus, lectin histochemistry of the longitudinal colonic groove (a, c, e, g) and of the ascending colon wall lining the main lumen (b, d, f, h). (a, b) SBA. (c, d) RCA-I. (e, f) PNA. (g, h) UEA-I. Arrow, glycocalyx; Go, goblet cell. Scale bar: 30 $\mu \mathrm{m}(\mathrm{a}-\mathrm{c}) ; 25 \mu \mathrm{m}(\mathrm{d}-\mathrm{g}) ; 50 \mu \mathrm{m}(\mathrm{h})$ 

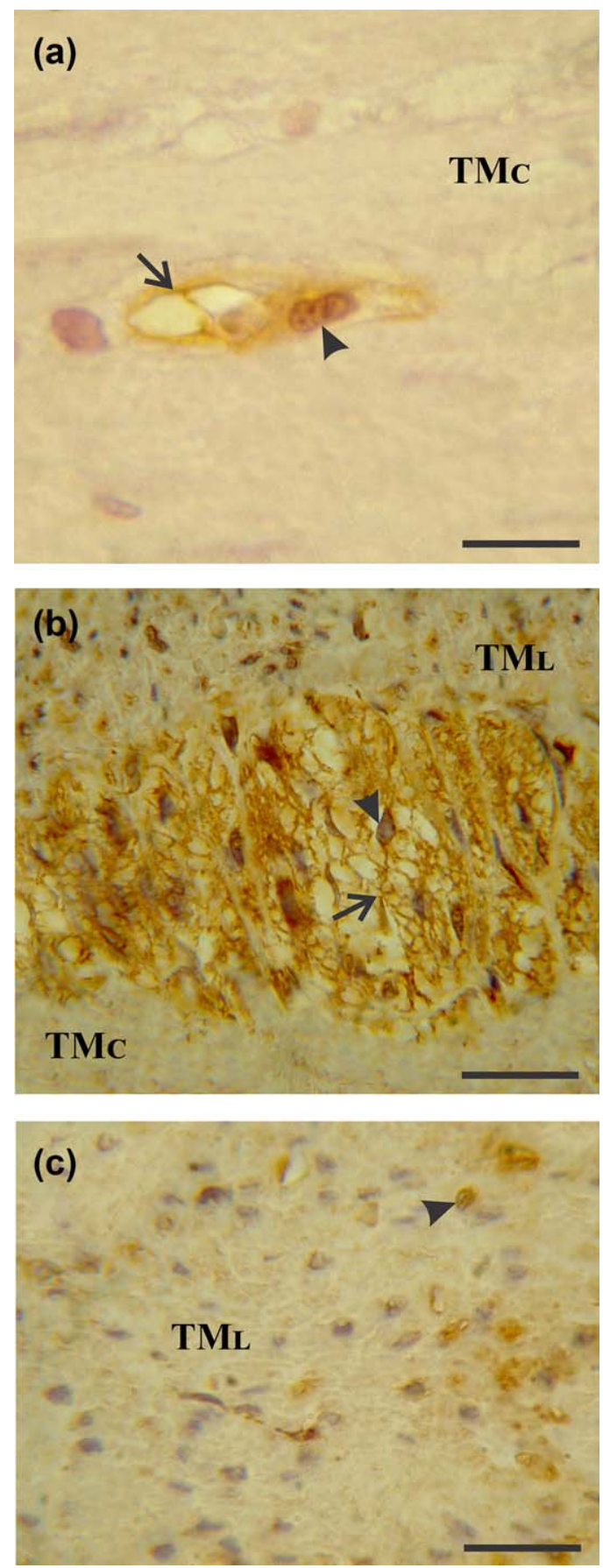

FIGURE 8 Lagostomus maximus, immunohistochemistry anti-c-kit of the ascending colon wall lining the main lumen. (a) Positive cells in the circular layer of the tunica muscularis. (b) Positive cells at the myenteric plexus level. (c) Positive cells in the longitudinal layer of the tunica muscularis. Arrow, cytoplasmic prolongation; arrow head, ICC; TMC, inner circular layer of the tunica muscularis; $\mathrm{TM}_{\mathrm{L}}$, outer longitudinal layer of the tunica muscularis. Scale bar: $30 \mu \mathrm{m}$

1988; Takahashi \& Sakaguchi, 2000). Because the selective transport of bacteria to the cecum is produced by mucins secreted in the colonic groove the mechanism is considered mucus dependent (Sakaguchi, 2003). Although the CSM largely depends on the mucus synthesized by the groove goblet cells, no exhaustive study on the histochemical characteristics has been done until now. This is the first complete analysis on the glycosylation pattern of mucins secreted in and out of the colonic groove, since so far, most research has focused mainly on the morphological and physiological characteristics of this anatomic adaptation (Kotzé, van der Merwe, \& O’Riain, 2006; Kotzé et al., 2009; Snipes et al., 1988; Takahashi \& Sakaguchi, 2000, 2006).

The GCs analysis showed differences among goblet cells in and out of the colonic groove, this being the first time an abrupt change in the glycosylation pattern of the intestinal tract of L. maximus is described (Tano de la Hoz et al., 2014, 2016). The observed variation of the ascending colon histochemical profile at the ridges level suggests that the glycosylation pattern of mucus plays a key role in the functioning of the groove of L. maximus. As described by Hansson (2012), mucus can trap bacteria in the intestinal tract lumen in many ways. First, bacteria can get trapped into the mucin polymeric network or they may bind to the great variety of mucus glycans through fimbrial and afimbrial adhesins which specifically recognize different types of carbohydrate residues. Because of the significance of mucus composition in bacterial aggregation, it is possible that the distinct histochemical profile of the colonic groove generate specific anchorage sites for the high density of bacteria in the region. In addition, as it has been demonstrated in other research, the presence of highly glycosylated mucins may limit the access of pathogenic bacteria to the cell surface by steric hindrance (McGuckin, Lindén, Sutton, \& Florin, 2011).

Published evidence shows that mucins interact with the intestinal microflora dynamically and adaptively (Corfield, 2015). Freitas, Axelsson, Cayuela, Midtvedt, \& Trugnan (2002) have shown that the microbiota induces modifications of the intestinal mucin glycosylation to produce an increase secretion of sulfated mucins. Similarly, our results documented that the mucus secreted by goblet cells of the colonic groove displays a greater proportion of sulfomucins than that produced by the rest of the goblet cells from the ascending colon. Diverse studies have demonstrated that sulfate groups confer mucus a greater resistance to degradation by bacterial glycosidases and host proteases (McGuckin et al., 2011; Roberton \& Wright, 1997). Moreover, studies on the ontogenetic development of the mammalian intestinal tract have demonstrated an increase in acidic mucin secretion during the fetal stages that would probably contribute to improve the innate immunological response in the prenatal stages (Beyaz \& Liman, 2009). In view of the foregoing background and because the colonic groove lumen transports more bacteria than the main lumen of the ascending colon (Takahashi \& Sakaguchi, 2006), it is possible that the sulfomucins secreted in the L. maximus colonic groove may be implicated in the protection of mucosa to prevent the proliferation of pathogenic bacteria.

As for the different types of sialomucins secreted by goblet cells, the histochemical analysis also revealed variations between the colonic groove and the main lumen. Although the presence of GCs with sialic acid residues was evidenced in all goblet cells from the ascending colon, our results demonstrated that only in the main lumen of $L$. 


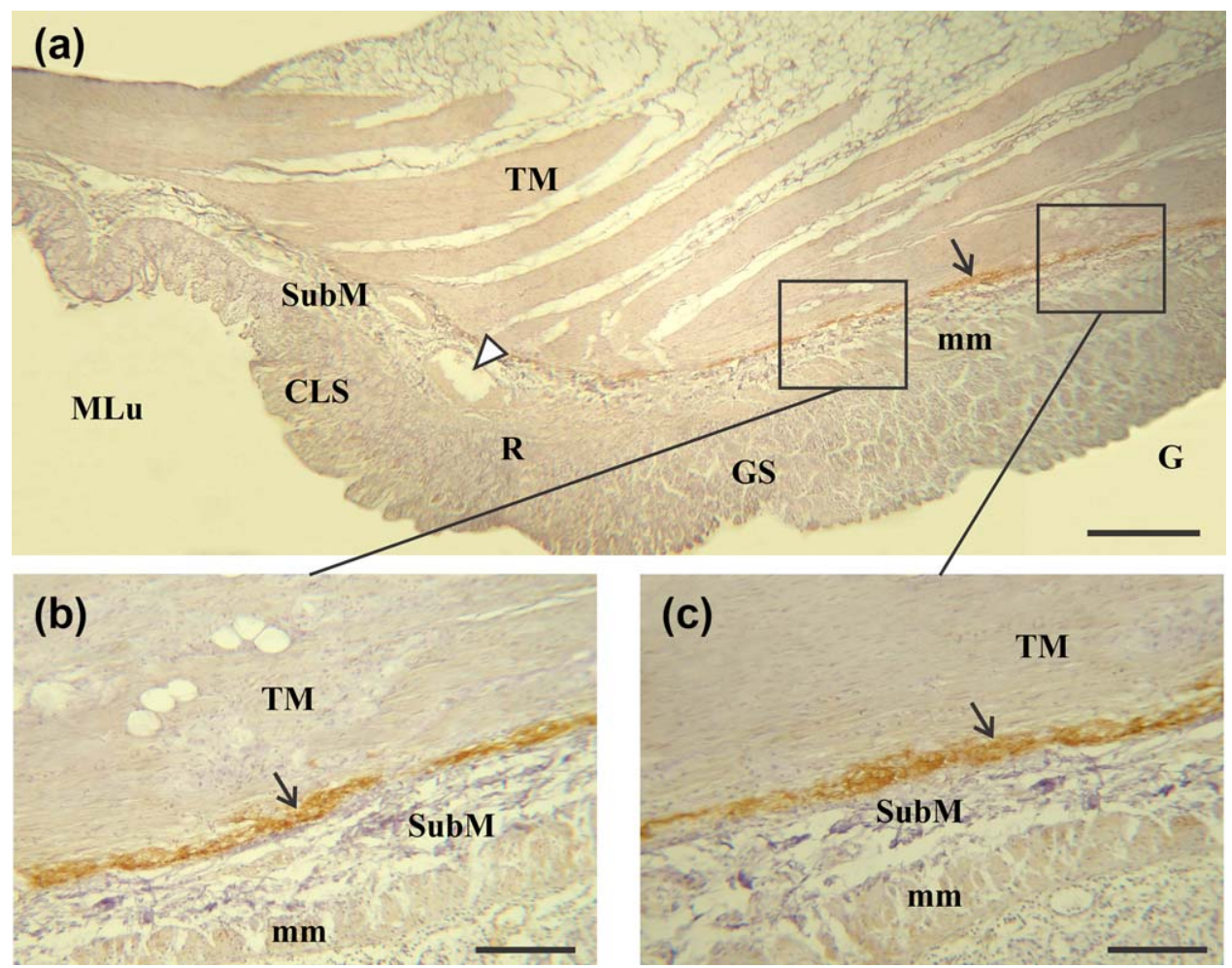

FIGURE 9 Lagostomus maximus, immunohistochemistry anti-c-kit of the colonic groove. (a) Microphotography of a ridge showing a continuous band of c-kit positive cells in the submucosa region limiting the tunica muscularis. (b, c) Detail of the tunica submucosa with c-kit positive cells. Arrow, ICC-SM; arrow head, large caliber vein; CLS, lateral border of the ridge limiting the main lumen; G, groove; Gs, lateral border of the ridge limiting the groove; MLu, main lumen; mm, muscular mucosa; R, ridge; SubM, tunica submucosa; TM, tunica muscularis. Scale bar: $500 \mu \mathrm{m}(\mathrm{a}) ; 100 \mu \mathrm{m}(\mathrm{b}, \mathrm{c})$

maximus GCs with sialic acid O-acyl substituted at C7, C8, or C9 are secreted. Similarly, other studies have described a high proportion of O-acetylated sialomucins in the colon of humans and rodents (Accili, Menghi, \& Gabrielli, 2008; Mastrodonato et al., 2013). As previously proposed, the acetylation of sialic acid residues can substantially modify its functional role in the diverse biological processes (Angata \& Varki, 2002). The higher degree of acetylation of sialic acid residues secreted by goblet cells from the main lumen alter the viscoelastic and protective properties of the mucus, and thus improving the resistance to bacterial neuraminidases (Mastrodonato et al., 2013).

The lectin binding pattern also presented some variations between the colonic groove and the main lumen of the ascending colon of $L$. maximus, in the glycocalyx as well as in the goblet cells. Freitas et al. (2002) showed that the lectin histochemical pattern of the secreted mucins. We suggest that the differences found in the present study may be also the result of the interaction between mucins and bacteria transported through the colonic groove.

\subsection{Distribution pattern of the interstitial cells of Cajal}

The motor activity of the gastrointestinal tract (GIT) is a complex physiological process that implies the interaction of three cell types: the enteric neurons, the interstitial cells of Cajal (ICC) and the smooth muscle cells (Mazet, 2015). Advances in the last decades have improved the comprehension of the ICC role in the GIT, and shown that they are an integral part of the gastrointestinal motor apparatus (Mazzone \& Farrugia, 2007). However, to the present there are no studies on the ICC-distribution pattern in the colonic groove of rodents. According to the classification made by Sanders, Ördög, Koh, Torihashi, \& Ward (1999), the immunohistochemical detection of ICC demonstrated the existence of different subpopulations in the ascending colon of $L$. maximus. Considering the numerous physiological studies performed on the ICC functional role (Mazzone and Farrugia, 2007; Sanders, Kito, Hwang, \& Ward, 2016; Sanders et al., 1999), we can infer that the diverse subtypes found would participate in the intestinal motility of $L$. maximus acting as mechanosensors, mediating in neurotransmission, facilitating the propagation of electrical events or acting as pacemaker cells. Even though the ICC from the submucosal surface of the circular muscle (ICC-SM) have been described as slow wave generating cells in other mammal's colon (Mazzone \& Farrugia, 2007), our results demonstrated that this subcellular type is within the ascending colon, restricted just to the colonic groove of L. maximus. Since Takahashi \& Sakaguchi (2000) have determined that the groove transports mainly bacteria in a retrograde way by antiperistaltic mechanisms, it is possible that the motor activity of this region may be related to the ICC-SM singular distribution pattern. 

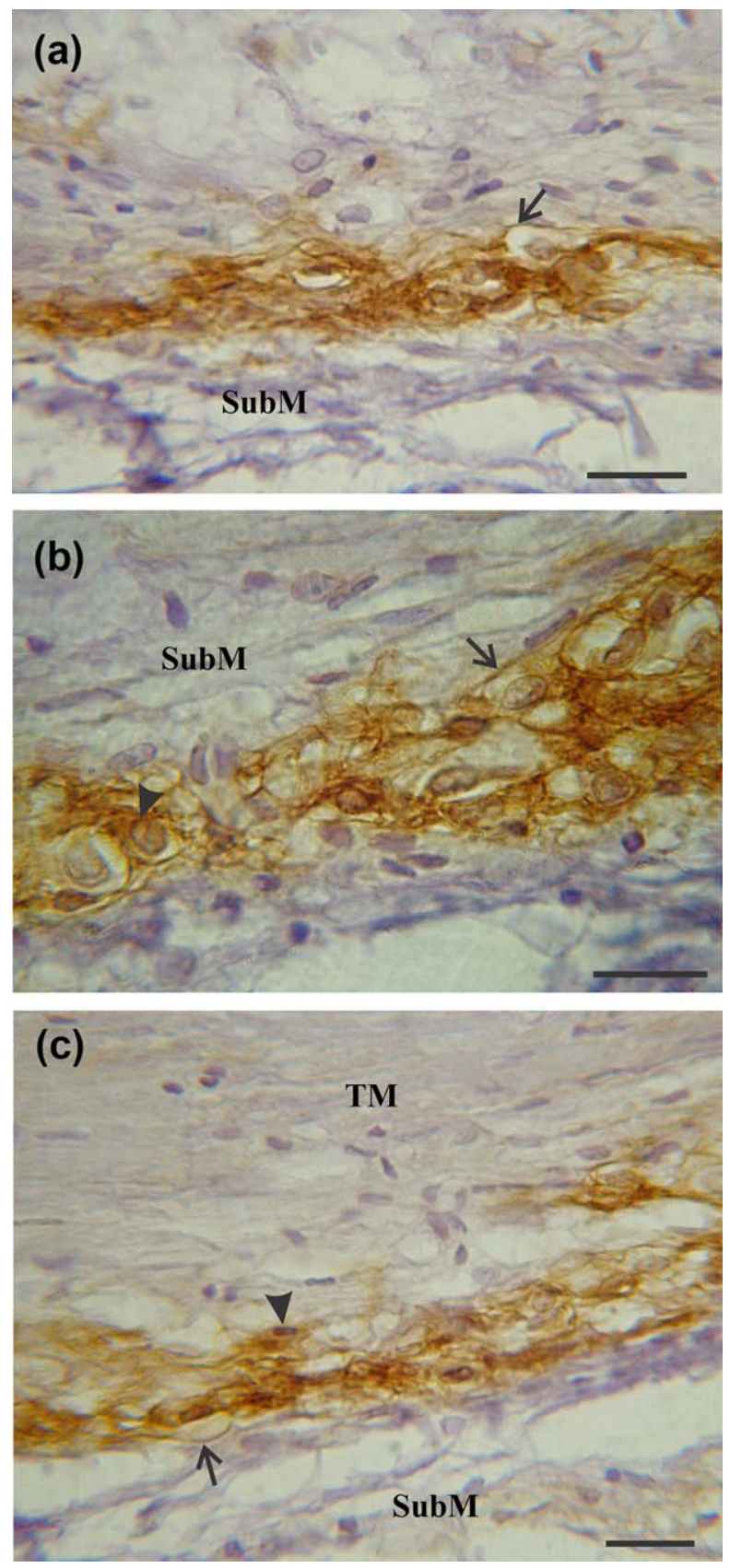

FIGURE 10 Lagostomus maximus, positive c-kit cells of the submucosal border. (a-c) Detail of the ICC-SM. Arrow head, ICC-SM; arrow, cytoplasmic prolongation; SubM, tunica submucosa; TM, tunica muscularis. Scale bar: $30 \mu \mathrm{m}$

\section{ACKNOWLEDGMENTS}

This research was supported by a Grant from Universidad Nacional de Mar del Plata (EXA 765/16), Buenos Aires, Argentina. M.F.T.d.I.H and C.N.Z are members of CONICET, Argentina. We thank the staff of Estación de Cría de Animales Silvestres (ECAS), Ministerio de Agroindustria de la Provincia de Buenos Aires.

\section{AUTHOR CONTRIBUTIONS}

The study was designed by A.O.D. and A.M.F. and was undertaken by M.F.T.d.I.H. as part of her doctoral thesis. M.F.T.d.I.H. performed the experiments and analyzed data. C.N.Z. provided technical assistance with IHC staining and participated in the analysis of the results. All authors wrote the manuscript and approved the final submission.

\section{REFERENCES}

Accili, D., Menghi, G., \& Gabrielli, M. G. (2008). Lectin histochemistry for in situ profiling of rat colon sialoglycoconjugates. Histology and Histophatology, 23, 863-875.

Angata, T., \& Varki, A. (2002). Chemical diversity in the sialic acids and related $\alpha$-keto acids: An evolutionary perspective. Chemical Reviews, 102, 439-469.

Bansil, R., \& Turner, B. S. (2006). Mucin structure, aggregation, physiological functions and biomedical applications. Current Opinion in Colloid \& Interface Science, 11, 164-170.

Beyaz, F., \& Liman, N. (2009). The prenatal development and histochemistry of the ileal mucins in the bovine fetuses. Anatomia, Histologia, Embryologia, 38, 436-442.

Björnhag, G., \& Snipes, R. L. (1999). Colonic separation mechanism in lagomorph and rodent species-A comparison. Mitteilungen Aus Dem Museum Für Naturkunde in Berlin, 75, 275-281.

Bontti, E. E., Boo, R. M., Lindström, L. I., \& Elia, O. R. (1999). Botanical composition of cattle and vizcacha diets in central Argentina. Journal of Range Management, 52, 370-377.

Branch, L. C., Villarreal, D., Sbriller, A. P., \& Sosa, R. A. (1994). Diet selection of the plains vizcacha (Lagostomus maximus, family Chinchillidae) in relation to resource abundance in semi-arid scrub. Canadian Journal of Zoology, 72, 2210-2216.

Clauss, M., Besselmann, D., Schwarm, A., Ortmann, S., \& Hatt, J. M. (2007). Demonstrating coprophagy with passage markers? The example of the plains viscacha (Lagostomus maximus). Comparative Biochemistry and Physiology Part A: Molecular \& Integrative Physiology, 147(2), 453-459.

Commission on Life Sciences National Research Council. (1996). Institute of laboratory animals resources. Guide for the care and use of laboratory animals. Washington, DC: Editorial National Academic Press.

Corfield, A. P. (2015). Mucins: A biologically relevant glycan barrier in mucosal protection. Biochimica Et Biophysica Acta, 1850, 236-252.

Culling, C. F. A., Reid, P. E., \& Dunn, W. L. (1976). A new histochemical method for the identification and visualization of both side-chain acylated and non-acylated sialic acids. Journal of Histochemistry and Cytochemistry, 24, 1225-1230.

Forstner, J. F., Oliver, M. G., \& Sylvester, F. A. (1995). Production, structure and biologic relevance of gastrointestinal mucins. In M. J. Blaser, P. D. Smith, J. I. Ravdin, H. B. Greenberg, \& R. L. Guerrant (Eds.), Infections of the gastrointestinal tract (pp. 71-88). New York: Raven Press.

Freitas, M., Axelsson, L. G., Cayuela, C., Midtvedt, T., \& Trugnan, G. (2002). Microbial-host interactions specifically control the glycosylation pattern in intestinal mouse mucosa. Histochemistry and Cell Biology, 118, 149-161.

Hagen, K. B., Besselmann, D., Cyrus-Eulenberger, U., Vendl, C., Ortmann, S., Zingg, R., ... Clauss, M. (2015). Digestive physiology of the plains viscacha (Lagostomus maximus): A large herbivorous hystricomorph rodent. Zoo Biology, 34(4), 345-359.

Hansson, G. C. (2012). Role of mucus layers in gut infection and inflammation. Current Opinion in Microbiology, 15, 57-62.

Jackson, J. E., Branch, L. C., \& Villarreal, D. (1996). Lagostomus maximus. Mammal Species, 543, 1-6. 
Kim, Y. S., \& Ho, S. B. (2010). Intestinal goblet cells and mucins in health and disease: Recent insights and progress. Current Gastroenterology Reports, 12, 319-330.

Kotzé, S. H., van der Merwe, E. L., Ndou, R., O'riain, M. J., \& Bennett, N. C. (2009). The colonic groove or furrow: A comparative morphological study of six species of African mole-rats (Rodentia, Bathyergidae). Journal of Morphology, 270, 966-975.

Kotzé, S. H., van der Merwe, E. L., \& O'riain, M. J. (2006). The topography and gross anatomy of the gastrointestinal tract of the Cape Dune mole-rat (Bathyergus suillus). Anatomia, Histologia, Embryologia, 35, 259-264.

Lev, R. A., \& Spicer, S. S. (1964). Specific staining of sulphate groups with Alcian Blue at low pH. Journal of Histochemistry and Cytochemistry, 12, 309-309.

Liquori, G. E., Mastrodonato, M., Mentino, D., Scillitani, G., Desantis, S., Portincasa, P., \& Ferri, D. (2012). In situ characterization of O-linked glycans of Muc2 in mouse colon. Acta Histochemica, 114, 723-732.

Lison, L. (1953). Histochimie et cytochimie animales. Principes et méthodes (607 p.). Paris: Gauthier-Villars.

Martino, N. S., Zenuto, R. R., \& Busch, C. (2007). Nutritional responses to different diet quality in the subterranean rodent Ctenomys talarum (tuco-tucos). Comparative Biochemistry and Physiology A, 147, 974-982.

Mastrodonato, M., Mentino, D., Liquori, G. E., \& Ferri, D. (2013). Histochemical characterization of the sialic acid residues in mouse colon mucins. Microscopy Research and Technique, 76, 156-162.

Mazet, B. (2015). Gastrointestinal motility and its enteric actors in mechanosensitivity: Past and present. Pflügers Archiv European Journal of Physiology, 467, 191-200.

Mazzone, A., \& Farrugia, G. (2007). Evolving concepts in the cellular control of gastrointestinal motility: Neurogastroenterology and enteric sciences. Gastroenterology Clinics of North America, 36, 499-513.

Mc Manus, J. F. A. (1948). Histological and histochemical uses of periodic acid. Stain Technology, 23, 99-108.

McGuckin, M. A., Lindén, S. K., Sutton, P., \& Florin, T. H. (2011). Mucin dynamics and enteric pathogens. Nature Reviews Microbiology, 9, 265-278.

Mess, A., \& Ade, M. (2005). Feeding biology of the dassie-rat Pteromus typicus in captivity. Belgian Journal of Zoology, 135, 45-51.

Mowry, R. W. (1963). The special value of methods that colour both acidic and vicinal hydroxyl groups in the histochemical study of mucins with revised directions for the colloidal iron stain, the use of Alcian blue 8GX, and their combination with the periodic acidSchiff reaction. Annals of the New York Academy of Sciences, 106, 402-423.

Pearse, A. G. E. (1985). Histochemistry: Theoretical and applied (Vol. 2, 631 p.). Edinburgh: Churchill Livingstone.

Puig, S., Videla, F., Cona, M., Monge, S., \& Roig, V. (1998). Diet of the vizcacha Lagostomus maximus (Rodentia, Chinchillidae), habitat preferences and food availability in Northern Patagonia. Argentina. Mammalia, 62, 191-204.

Reid, P. E., Culling, C. F. A., \& Dunn, W. L. (1973). Saponification induced increase in the periodic acid Schiff reaction in the gastrointestinal tract. Mechanism and distribution of the reactive substance. Journal of Histochemistry and Cytochemistry, 21, 473-482.

Roberton, A. M., \& Wright, D. P. (1997). Bacterial glycosulphatases and sulphomucin degradation. Canadian Journal of Gastroenterology, 11, 361-366.

Sakaguchi, E. (2003). Digestive strategies of small hindgut fermenters. Animal Science Journal, 74, 327-337.

Sanders, K. M., Kito, Y., Hwang, S. J., \& Ward, S. M. (2016). Regulation of gastrointestinal smooth muscle function by interstitial cells. Physiology, 31, 316-326.

Sanders, K. M., Ördög, T., Koh, S. D., Torihashi, S., \& Ward, S. M. (1999). Development and plasticity of interstitial cells of Cajal. Neurogastroenterology \& Motility, 11, 311-338.

Scillitani, G., \& Mentino, D. (2015). Comparative glycopattern analysis of mucins in the Brunner's glands of the guinea-pig and the house mouse (Rodentia). Acta Histochemica, 117, 612-623.

Snipes, R. L., Hörnicke, H., Björnhag, G., \& Stahl, W. (1988). Regional differences in hindgut structure and function in the nutria, Myocastor coypus. Cell and Tissue Research, 252, 435-447.

Takahashi, T., \& Sakaguchi, E. (1998). Behaviors and nutritional importance of coprophagy in captive adult and young nutrias (Myocastor coypus). Journal of Comparative Physiology B, 168, 281-288.

Takahashi, T., \& Sakaguchi, E. (2000). Role of the furrow of the proximal colon in the production of soft and hard feces in nutrias, Myocastor coypus. Journal of Comparative Physiology B, 170, 531-535.

Takahashi, T., \& Sakaguchi, E. (2006). Transport of bacteria across and along the large intestinal lumen of guinea pigs. Journal of Comparative Physiology B, 176, 173-178.

Tano de la Hoz, M. F., Flamini, M. A., \& Díaz, A. O. (2014). Histological and histochemical study of the duodenum of the plains viscacha (Lagostomus maximus) at different stages of its ontogenetic development. Acta Zoologica, 95, 21-31.

Tano de la Hoz, M. F., Flamini, M. A., \& Díaz, A. O. (2016). Comparative analysis of the morphology, ultrastructure, and glycosylation pattern of the jejunum and ileum of the wild rodent Lagostomus maximus. The Anatomical Record, 299, 630-642.

Volz, D., Reid, P. E., Park, C. M., Owen, D. A., \& Dunn, W. L. (1987). A new histochemical method for the selective periodate oxidation of total tissue sialic acids. Histochemistry Journal, 19, 311-318.

Zuñiga, M., Tur Marí, J., Milocco, S., \& Pineiro, R. (2001). Ciencia y Tecnología en Protección y Experimentación Animal. Madrid: Editorial McGraw-Hill Interamericana.

How to cite this article: Tano de la Hoz MF, Flamini MA, Zanuzzi CN, Díaz AO. The colonic groove of the plains viscacha (Lagostomus maximus): Histochemical evidence of an abrupt change in the glycosylation pattern of goblet cells. Journal of Morphology. 2017;00:000-000. https://doi.org/10.1002/jmor. 20735 